Rapp. Grønlands geol. Unders. 69, 17-24 (1975)

\title{
LITHOSTRATIGRAPHY OF \\ THE EARLY TERTIARY VOLCANIC ROCKS OF CENTRAL WEST GREENLAND
}

Niels Hald and Asger Ken Pedersen

\begin{abstract}
Introduction
A sequence of flood basalts, in places more than $8-10 \mathrm{~km}$ thick, was erupted during the Early Tertiary in the central part of West Greenland between latitudes $69^{\circ}$ and $73^{\circ} \mathrm{N}$. The volcanic rocks rest on Precambrian metamorphic rocks and non-marine and marine sediments from the Cretaceous and Paleocene.

The lower part of the volcanic sequence is dominated by tholeiitic olivinerich basalts and picrite basalts, whereas the upper part is characterized by tholeiitic basalts with plagioclase as the dominant phenocryst mineral; transitional and alkaline lavas and tuffs are found, especially in the upper part of the sequence.

The geology of the Tertiary igneous rocks has been summarized by Munck \& Noe-Nygaard (1957), Rosenkrantz \& Pulvertaft (1969) and Clarke \& Pedersen (in press). However, until now no formal lithostratigraphy has been established. A geological map at scale 1:100 000 covering the greater part of Nûgssuaq (sheet Agatdal 70 V. 1 Nord) has been published by GGU.
\end{abstract}

\section{West Greenland Basalt Group \\ new group}

The volcanic rocks are all included in the West Greenland Basalt Group. The group has not been formally defined earlier, but the same unit has been described under a variety of names such as 'the Floetz-trap formation' (Giesecke, 1823), 'Trap-formationen' (Rink, 1853) and 'the basalt series' (Münther, 1973). 
Type area

Central West Greenland from Disko in the south to Ignerit in the north.

\section{Thickness}

From 0 to $8-10 \mathrm{~km}$.

\section{Lithology}

The group comprises basaltic and picrite basaltic lavas and pillow breccias (hyaloclastites) overlain by plagioclase-porphyritic basalts. Intermediate and acid volcanic rocks have been erupted in subordinate amounts. Sedimentary deposits belonging to the group occur at several levels. Dykes, sills and rarely larger intrusive bodies are, like the extrusive rocks, predominantly of basaltic or picrite basaltic composition.

The igneous rocks have generally tholeiitic affinity; alkaline rocks are, however, found, especially in the upper part of the volcanic sequence.

Clarke \& Pedersen (in press) review the geology of the igneous rocks of the West Greenland Basalt Group. On Disko the lithology of the group is described by Pedersen (1970), on Hareøen and western Nûgssuaq by Hald (in prep), on Ubekendt Ejland by Drever \& Game (1948) and Larsen (in prep), and on Svartenhuk Halv $\varnothing$ by Noe-Nygaard (1942) and Clarke (1970).

\section{Boundaries}

The group overlies unconformably Precambrian metamorphic rocks and Cretaceous to Lower Danian sediments, and interfingers in its lower part with the Upper Danian sediments of the Agatdal Formation (Rosenkrantz, in Koch, 1959, pp. 75-78) and the Upper Atanikerdluk Formation (Nordenskiöld, 1871; Troelsen, 1956).

The group represents the youngest pre-Quaternary rocks in the area.

\section{Distribution}

The group covers the major parts of Disko, central and western Nûgssuaq, Svartenhuk Halvø and Ignerit. Hareøen and Ubekendt Ejland are made up exclusively of rocks belonging to the group.

Age

Early Tertiary, Palaeocene to possibly Eocene. 


\section{Subdivisions}

The group is divided into three formations from below in ascending order: Vaigat Formation, Maligât Formation and Hareøen Formation.

\section{Vaigat Formation \\ new formation}

Volcanic rocks belonging to this formation have earlier been described as 'the Basalt Breccia Formation' (Noe-Nygaard, 1942), 'the Lower Lava Group' (Drever \& Game, 1948), 'the lower lava formation' (Pedersen, 1973) and 'the lower basalt series' (Münther, 1973).

\section{Name}

From the strait separating Disko and Nûgssuaq.

\section{Type area}

The north coast of Disko between Kûgánguaq and Asuk.

\section{Type section}

The type section is compounded from two exposures which together make up a complete succession. The lower part of the formation is exposed at Kûgángup ivnarta in a section towards point 1090 from an altitude of 0 to $750 \mathrm{~m}$, and the upper part is exposed at Manîdtlat kugssinerssuat from an altitude of $500 \mathrm{~m}$ to $1300 \mathrm{~m}$. The sections and their locations are shown in Pedersen (1973, figs 8-9, column VI (lower part) and column IV (upper part)).

\section{Thickness}

The thickness varies between 0 and $1.5-2 \mathrm{~km}$ on Disko, between 0 and more than $1.5 \mathrm{~km}$ on Nûgssuaq and between 0 and more than $3 \mathrm{~km}$ on Svartenhuk Halvø. On Ubekendt Ejland the formation is more than $5 \mathrm{~km}$ thick.

\section{Lithology}

The formation is dominated by picrite basalts in subaerial facies (lava) and in subaqueous facies (pillow breccias). In the volcanic pile subordinate sequences of olivine-poor, aphyric or plagioclase-porphyritic basalts occur. Mildly alkaline olivine basalts (Disko) and sediment-contaminated volcanic rocks, often with native iron (Disko and Nûgssuaq) are also present. 


\section{Boundaries}

The formation overlies unconformably Precambrian metamorphic rocks or Cretaceous to Lower Danian sediments. The formation interfingers with sediments of the Agatdal Formation and the Upper Atanikerdluk Formation.

The upper boundary with the plagioclase-porphyritic basaltic lavas of the Maligât Formation is sharp on north-eastern and central Disko and on northern Svartenhuk Halvø. Elsewhere the boundary, where exposed, is characterized by alternating sequences of olivine-rich basalts and aphyric or plagioclase-porphyritic basalts. On northern Disko the boundary is defined as the top of the uppermost sequence of thin, olivine-rich lavas typically with segregation veins.

\section{Distribution}

The formation covers the greater part of northern Disko, central Nûgssuaq and southern Svartenhuk Halv $\varnothing$. Furthermore, parts of Hareøen and Ubekendt Ejland consist of rocks from the formation.

Age

On palaeontological evidence from adjacent sediments (Rosenkrantz, 1970; Hansen, 1970; Perch-Nielsen, 1973; Jürgensen \& Mikkelsen, 1974) the formation is dated as Lower Palaeocene.

\section{Maligât Formation}

new formation

The basaltic lavas of the formation have earlier been termed 'the Upper Lava Group' (Drever \& Game, 1948), 'the upper basalt unit' (Rosenkrantz \& Pulvertaft, 1969), 'the upper basalt series' (Münther, 1973) and 'the upper lava formation' (Pedersen, 1970; Hald, 1973). A sequence of interbasaltic sediments on western Nûgssuaq has been described as 'Ifsorisoklagren' (Ifsorisok layers) by Nordenskiöld (1871) and Ifsorisok Formation by Koch (1964).

\section{Name}

From Maligât, the strait between Disko and Hareøen.

Type area

Nûgssuaq west of the Itivdle valley. 


\section{Type section}

The type section is compounded from two exposures. The lower part of the formation is exposed along the north coast of Nûgssuaq between Qutârdluk and Kanísut and the upper part is exposed along the west coast between Nûgssûta and Kangeq.

Neither the boundary with the older Vaigat Formation nor the boundary with the younger Hareøen Formation is exposed in the type area. Western Nûgssuaq has however been chosen as the type area because of the greater thickness of the formation there as compared with Disko.

\section{Reference sections}

The boundary with the Vaigat Formation is well exposed on northern Disko in the upward continuation of the upper part of the type profile through the Vaigat Formation (Pedersen, 1973, fig. 8, column IV). The boundary with the lavas of the younger Hareøen Formation is exposed in a gully above Talerua on the northeast coast of Hareøen.

\section{Thickness}

The exposed thickness is $3000 \mathrm{~m}$ on Nûgssuaq and 1500-2000 m on Disko. In most places the formation represents the youngest pre-Quaternary rocks of the area.

\section{Lithology}

Plagioclase-olivine-augite porphyritic basaltic lavas with tholeiitic affinity dominate the formation; intermediate and acid lavas and tuffs occur in subordinate amounts. Olivine-rich lavas resembling the flows in the Vaigat Formation are few and are commonest near the base of the formation. Alkaline, basic intermediate and acid lavas and tuffs are common on Ubekendt Ejland; elsewhere alkaline rocks are rare. Sediment-contaminated lavas with native iron are present on Disko.

Sediments belonging to the formation are present at several levels in the lava pile.

\section{Boundaries}

On eastern Disko the lavas from the Maligat Formation have transgressed beyond the lavas from the Vaigat Formation and cover Danian sediments from the Upper Atanikerdluk Formation. In central Disko and south-eastern Nûgssuaq the formation lies directly on Precambrian metamorphic rocks. Also north of Svartenhuk Halvø the formation has a wider distribution than the Vaigat Formation and covers Cretaceous-Lower Tertiary sediments and Precambrian metamorphic rocks.

The formation represents the youngest pre-Quaternary rocks in all areas except 
Hareøen. Here plagioclase-porphyritic basalts from the Maligât Formation are overlain by sediments and olivine-porphyritic basalts from the Hareøen Formation. No depositional contacts are exposed between the plagioclase-porphyritic lavas and the sediments; an angular unconformity exists between the former and the olivineporphyritic lavas.

Age

No age determination has been published for the Maligât Formation. Probably the formation is only a little younger than the Vaigat Formation (Palaeocene).

\section{Hareфen Formation \\ new formation}

The rocks placed in the Hareøen Formation have not earlier been considered as a separate stratigraphical unit. Sediments belonging to the formation have been mentioned by e. g. Giesecke (1910) and Steenstrup (1883). The basaltic lavas are described by Pedersen (1970) and Hald (in prep).

Name

From Hareøen.

Type area

South-eastern part of Hareøen. The lower part of the formation which comprises sediments is only exposed in situ in a gully above the south coast of Hareøen $5 \mathrm{~km}$ west of Niaqua.

\section{Thickness}

The maximum thickness exposed is $300 \mathrm{~m}$.

\section{Lithology}

Sediments dominated by sandstone and mudstone with coal seams are overlain by $1-10 \mathrm{~m}$ thick pahoehoe or aa lavas consisting of olivine-porphyritic transitional basalt.

\section{Boundaries}

The sediments are usually only exposed in landslides and no contacts with the Maligât Formation have been found. Above Talerua at the north-east coast the 
transitional lavas have transgressed beyond the sediments and overlie the lavas from the Maligât Formation with an angular unconformity.

The formation represents the youngest pre-Quaternary rocks on Hareøen.

\section{Distribution}

The formation is known only from Hareøen, where it crops out along the south coast and along the eastern part of the north-east coast excluding the promontory Niaqua.

Age

No age determinations have been published, but the formation is believed to be of approximately the same age as the Maligât Formation.

\section{References}

Clarke, D. B. 1970: Tertiary basalts of Baffin Bay: posșible primary magma from the mantle. Contr. Mineral. Petrol. 25, 203-224.

Clarke, D. B. \& Pedersen, A. K. in press: The Tertiary volcanic province of West Greenland. In: Escher, A. \& Watt, W. S. (edit) Geology of Greenland. Copenhagen: Geol. Surv. of Greenland.

Drever, H. I. \& Game, P. M. 1948: The geology of Ubekendt Ejland, West Greenland, Part 1. A preliminary review. Meddr Grønland 134, 8, 35 pp.

Giesecke, K. L. 1823: On the mineralogy of Disko Island. Trans. roy. Soc. Edinb. 9, 263-272.

[Giesecke, K. L.] 1910: Karl Ludwig Gieseckes mineralogisches Reisejournal über Grönland, 1806-1813. Meddr Grønland 35, 247-297.

Hald, N. 1973: Preliminary results of the mapping of the Tertiary basalts in western Nûgssuaq. Rapp. Grønlands geol. Unders. 53, 11-19.

Hald, N. in prep: Early Tertiary flood basalts from Hareøen and western Nûgssuaq, West Greenland.

Hansen, H. J. 1970: Danian foraminifera from Nûgssuaq, West Greenland, with special reference to species ocurring in Denmark. Bull. Grønlands geol. Unders. 93 (also Meddr Grønland 193, 2) 132 pp.

Jürgensen, T. \& Mikkelsen, N. 1974: Coccoliths from volcanic sediments (Danian) in Nûgssuaq, West Greenland. Bull. geol. Soc. Denmark 23, 225-230.

Koch, B. E. 1959: Contribution to the stratigraphy of the nonmarine Tertiary deposits on the south coast of Nûgssuaq peninsula, northwest Greenland with remarks on the fossil flora. Bull. Grønlands geol. Unders. 22 (also Meddr Grønland 161, 1) 100 pp.

Koch, B. E. 1964: Review of fossil floras and nonmarine deposits of West Greenland. Bull. geol. Soc. Amer. 75, 535-548.

Larsen, J. G. in prep: Fieldwork on Ubekendt Ejland in the Tertiary basalt province of West Greenland 1971 and 1973.

Munck, S. \& Noe-Nygaard, A. 1957: Age determination of the various stages of the Tertiary volcanism in the west Greenland basalt province. 20th int. geol. Congr., Mexico, 1956 1, 247-256. 
Münther, V. 1973: Results from a geological reconnaissance around Svartenhuk Halv $\varnothing$, West Greenland. Rapp. Grønlands geol. Unders. 50, 26 pp.

Noe-Nygaard, A. 1942: On the geology and petrography of the West Greenland basalt province. Part 3. The plateaubasalts of Svartenhuk Peninsula. Meddr Grønland 137, 3, 78 pp.

Nordenskiöld, A. E. 1871: Redogörelse för en Expedition till Grönland år 1870. Öfvers. VetenskAkad. Förh., Stockh. 27, 973-1082.

Pedersen, A. K. 1970: En petrologisk unders $\phi$ gelse af Tertiære vulkanske bjergarter fra det nordiige Disko. Unpublished prize dissertation, Univ. of Copenhagen. Reviewed in Festskrift Københavns Univ. 1970, 379-383.

Pedersen, A. K. 1973: Report on field work along the north coast of Disko, 1971. Rapp. Grønlands geol. Unders. 53, 21-27.

Perch-Nielsen, K. 1973: Danian and Campanian/Maastrichtian coccoliths from Nûgssuaq, West Greenland. Bull. geol. Soc. Denm. 22, 79-82.

Rink, H. 1853: Udsigt over Nordgrønlands geognosi, især med Hensyn til Bjergmassernes mineralogiske Sammensætning. $K$. danske Vidensk. Selsk. Skr 5. række Naturv. math. 3, 71-98.

Rosenkrantz, A. 1970: Marine Upper Cretaceous and lowermost Tertiary deposits in West Greenland. Meddr dansk geol. Foren. 19, 406-453.

Rosenkrantz, A. \& Pulvertaft, T. C. R. 1969: Cretaceous-Tertiary stratigraphy and tectonics in northern West Greenland. Mem. Am. Ass. Petrol. Geol. 12, 883-898.

Steenstrup, K. J. V. 1883: Om Forekomsten af Forsteninger i de kulførende Dannelser i Nord-Grønland. Meddr Grønland 5, 43-77.

Troelsen, J. C. 1956: Lexique stratigraphique International. 1 (1a) Groenland. Congres Géologique International, Comm. Stratigr. Paris. 